weeks without any cows having been in season. The maiden cows and a few old cows without calves collect on the surf-ringed skerry of Loba Sgeir and mate there with young bulls. It was exceptionally interesting to observe that all these animals lay cheek by jowl without any apparent expression of territorial behaviour. The young stock does not come inland.

After the breeding season a large proportion of the adult stock gathered on Loba Sgeir and lay quiet there until they had moulted their coats. They leave Rona then to feed about the Hebridean coasts until the next season.

The Atlantic grey seal calf is thin when born but puts on fat at a very rapid rate. Its fluffy white coat begins to be shed at a fortnight old and it is then that lactation in the cow rapidly declines and maternal care ceases. The calves face starvation until they reach the sea, and from a cliff-bound island that journey is a perilous one.

The occupation of the northern peninsula of Rona by the seals affects the vegetative complex and creates a favourable environment for Chironomid larvæ. Thus the island is a fruitful port of call for migrant birds and a place of immense consequence to many others. In any attempt to conserve our country's wild life we should not forget the little islands, for they have a value as sanctuaries far beyond that which their size would indicate. Rona, where man has failed to survive, is one of the great cities of this earth.

\title{
Scientific Approach to Milk Policy
}

$\mathrm{M}^{\mathrm{A}}$ ANY members of the British Association for the Advancement of Science have been feeling during the past three or four years that more efficient machinery should be devised by the Association for the consideration of the effects on society of scientific developments and discoveries, and for the application of scientific methods to social ends. At the Cambridge meeting of the Association in August last, it was decided to constitute a new Division of the Association to be concerned with social and international relations of science, and Sir Richard Gregory was elected the first chairman. It was later decided that the Division should hold meetings, at times intermediate between those of the normal annual meetings of the Association, at different centres in Great Britain and elsewhere.

The Nutrition Sub-Committee of the new Division has been the first to get off the mark, and, at the University of Reading on March 28, held a one-day conference on milk, in its nutritional and allied aspects. It is a commonplace that the handling of the milk question is the most awkward problem in any long-range policy concerned with improvement either in general health or in agriculture, and the boldness of the young Division in firmly grasping this important domestic nettle at its first meeting is a good augury for its future activities. In view of the trying weather, the attendance (about 180 were present at the main session) cannot be regarded as other than satisfactory.

The day began with a visit of the more weatherresistant members to the National Institute for Research in Dairying at Shinfield near Reading.
Here the party was shown, by the Director and staff, experimental work on various ad hoc dairy industry questions, and also on some of the more fundamental problems of dairy science. Amongst the investigations described were those on the protein requirements of dairy cattle, on new methods for the pasteurization of milk, on the effect of various types of commercial processing on the nutritive value of milk, on the causes of low compositional quality in milk, and on the hormonal control of lactation. The new chemical and physiological laboratories now rapidly approaching completion, and the completely rebuilt dairy machinery testing centre were inspected, and the memorial library and the recently founded Imperial Bureau of Dairy Science visited.

After lunching at the University, members met for the afternoon session in the Great Hall, where the Vice-Chancellor (Sir Franklin Sibly) welcomed the Association on behalf of the University. The chair was taken by Sir Richard Gregory, who introduced the three principal speakers, Dr. Harriette Chick, Prof. J. C. Drummond and Dr. A. W. Scott. The papers given by these three dove-tailed so closely into one another that it is more convenient in this brief report to deal with them together.

The factual basis for the emphasis which has been laid on the importance of milk in the national dietary was re-described, and the food value of milk products, for example skim milk, was discussed. Despite its food value, milk is rather an awkward material to handle and distribute, and a potentially dangerous material for the consumer if it is not properly produced and processed. Whilst Great 
Britain lingers rather far behind several other countries (such as Sweden, Switzerland, Norway, the United States), in liquid milk consumption per head, yet when dairy products such as butter, cheese, cream, dried milk, etc., are taken into account at their liquid milk equivalent, our consumption of liquid milk plus milk products puts us in a high position on the list, the consumption having increased from $322 \mathrm{kgm}$. per head per year in 1925-29, and $403 \mathrm{kgm}$. in 1930-31, to $548 \mathrm{kgm}$. in 1934. The dietetic value of milk is practically unaltered by properly controlled commercial pasteurization, and little affected even by sterilization and drying. This recent conclusion is the result of carefully controlled feeding and other experiments carried out at the National Institute for Research in Dairying and at the Rowett Institute, and also in elementary schools in England during the past four years, under the auspices of the Milk Nutrition Committee (chairman, Lord Astor). These findings and those obtained by other responsible investigators have finally disposed of the fallacy that commercial methods of pasteurization seriously damage the food value of milk. Kon has shown that one of the most labile constituents of milk, vitamin C, is, in milk, actually more sensitive to light than to heat, though milk is, in any event, a poor source of this vitamin. In view of the potential danger of drinking raw milk, exemplified from the health records of past years, which show how much ill-health is directly traceable to an infected milk supply, it was stated that no good scientific reason exists why the pasteurization of all milk for liquid consumption should not now be enforced.

The implications of such a policy were dealt with in some detail. A very large proportion of the milk supply of Great Britain is already heat-treated, but frequently inefficiently heat-treated, so that disease organisms are not completely destroyed, though the keeping quality of the milk may be improved. One of the advantages of compulsory pasteurization would be that supervision of commercial heat-treatment could be made much more efficient than at present, particularly now that the phosphatase test is available. Objections to compulsory pasteurization on the grounds that it would lessen the stimulus to the eradication of disease in dairy herds, or that it would cause farmers to relax their efforts towards clean milk production, or that it would put the whole industry in the hands of the large distributing combines, were stated to be without foundation. With reference to this last objection the control of the industry is now, in fact, in the hands of the largest possible combines-the producers' marketing boards.

Following the principal speakers, there was a short discussion. One of the most important points in favour of compulsory pasteurization was made during the discussion-namely, that it would actually help the producer by increasing public confidence, and the confidence of medical men (who in matters of nutrition are frequently the mentors of the public) in the safety of the milk supply. A rather loosely worded resolution was passed by the divisional meeting, for consideration by the Council of the British Association, recommending that pasteurization of all milk to be sold in their areas should be enforced by all authorities dealing with a population of 20,000 or above.

It would perhaps be an exaggeration to say that this resolution is battering at an open door. It is no secret that the big producers' organizations in Great Britain are not opposed to compulsory pasteurization at least as applied to the large municipal areas, with a stipulation that a supply of raw tuberculin-tested milk should be available for those individuals who really prefer raw milk. The Government too, in 1938, accepted the principle of compulsory pasteurization and had incorporated it, with certain safeguards, in the very comprehensive and well-thought-out Milk Industry Bill, which was withdrawn a few months ago. That the withdrawal was on account of the compulsory pasteurization clauses seems highly unlikely.

Quite apart from new legislation, however, a suggestion, admittedly not novel, was made informally after the meeting which, if put into action, might greatly ameliorate the risk, from the consumer's point of view, of milk-borne disease. Heavy penalties could presumably be exacted at common law from any retailer who had sold milk which could be proved to have caused disease in the consumer; if this were done in one or two cases, it is not unreasonable to suppose that raw milk distributors themselves would feel disinclined to continue to risk nc $\downarrow$ merely the consumer's health, but also their own reputation, trade and pocket, by selling unsafe milk in the future.

During the evening session, the chair was taken by Sir Daniel Hall, and two papers, one by $\mathrm{Mr}$. James Mackintosh on milk production, and the other by Mr. John Cripps on milk distribution and costs were given. The main problem of increased production in Great Britain to meet a steadily increasing demand for liquid milk was stated to be, at least in the early stages of this demand, that of increasing the winter supply, which in November, December, and January is at present very close to the minimum required to cover the needs of the liquid trade.

It would be possible to even out supplies during the year by arranging for more cows to calve in autumn. Again, far better yields per cow than those obtained at present are possible in many herds by making use of knowledge already available 
on feeding and management, and on methods of breeding. In urban distribution, it was pointed out that the consumer is suffering under a surfeit of retailers, many of whom could be dispensed with, and of 'services' many of which are quite superfluous with properly processed milk. If surplus retailers and these costly but unnecessary services could be dispensed with, consumer prices could be reduced. But without monopoly in some form or another, it is not easy to see how a stable scheme for effective and minimum-cost distribution could be brought about. It was suggested that, instead of further verbal discussion of hypothetical alternatives, some experiments on different types of monopoly control, for example, municipal, co-operative, public utility, private firm, ought to be tried out under careful supervision in limited areas. But this type of experiment cannot take place without legislation.

From the events of this most interesting day, one point emerges very clearly. This Division of the British Association by its very nature cannot proceed far without becoming involved, and involved very deeply, in politics and in active social planning. While this is well understood by the officers of the Division, it seemed to be somewhat of a revelation to several of those others who attended the Reading meeting.

\section{Obituary Notices}

\section{Miss Dorothea F. M. Pertz}

D ORA PERTZ, who died on March 6, a few days before reaching her eightieth birthday, was born in 1859 into a cosmopolitan, intellectual milieu, for which it would be difficult to-day to find a parallel. Her father was Dr. G. H. Pertz, a scholar of worldwide repute, and Royal Librarian in Berlin. His first wife was a brilliant Englishwoman, who counted Sismondi and Lafayette among her friends. His second wife, Dora's mother, also an Englishwoman, was one of a remarkable group of sisters, the six daughters of Leonard Horner, a prominent early member of the Geological Society, and twice its president. He was evidently a man of unusual breadth of view, for though he was burn at so remote a date as 1785 , he was sufficiently open-minded to commend Darwin's speculations in his last address to the Geological Society in 1861. Horner's eldest daughter was married to Sir Charles Lyell, and his second daughter to Sir Charles J. F. Bunbury, a botanist, who, under lyell's influence, turned his attention to fossil plants.

Among the Horners, scientific enthusiasm was by no means confined to the men. Dora Pertz's grandmother helped her husband with his rock collections, and when the meetings of the Geological Society were first thrown open to women visitors, Dora's aunts, Lady Lyell and her sisters, were constant in their attendance, though otherwise few women cared to avail themselves of this privilege. Katharine Horner, who married Lyell's brother, and eventually became the biographer of her father and her brothers-in-law, was a botanist. She published in 1870 "A Geographical Handbook of Ferns"- a highly technical catalogue dealing with the distribution of this group. Of Sir Charles Lyell, in his Harley Street period, Dora had certain childish recollections, especially of occasions when he would call a hansom cab and carry off his two small nieces for rapturous visits to the Zoo. Love of animals was throughout Dora's life a ruling passion, and her youthful memory of visiting the Darwins at Down, centred in the joy of being allowed to caress the nose of the horse on which Charles Darwin was riding, in his cloak and broad-brimmed hat.

When her father,died, Dora Pertz went with her mother and sister to live in Florence, but, after some years in Italy, the family urge towards science brought her to England in 1882, in order to enter Newnham College. Having taken honours in the Natural Sciences Tripos, she continued to work at Cambridge, doing research in plant physiology under the direction of Francis Darwin, who was then a member of the staff of the Botany. School. Dora Pertz co-operated in much of his work, and also produced several independent papers. The best known of their joint memoirs is probably that "On the Artificial Production of Rhythm in Plants", published in the Annals of Botany of 1892 . She also did some genetical work in the days when that study was just beginning at Cambridge, and collaborated with William Bateson in a paper on inheritance in Veronica.

After Sir Francis Darwin's retirement. Dora Pertz continued for a time to make observations; but she came to recognize that the plant physiology of the twentieth century was developing on lines widely divergent from those on which she had been educated, and that it demanded a grasp of mathematics, physics, and chemistry, which she did not possess. With characteristic clear-sightedness as to her own limitations, she desisted from attempting to do research for which her equipment was inadequate, and she sought for some other means through which she could be of use to botany. Fortunately, Dr. F. F. Blackman was able to enlist her services in cataloguing pamphlets, and in making an elaborate index of the papers of plant physiological interest in the numerous early volames of the Biochemische Zeitschrift and the Zeitschrift der physiologischen Chemie. She completed tho index up to the year 1935 ; the magnitude of the task may be judged 